Jean-Baptiste Guillaumin, Carlos Lévy (eds.), Plato latinus. Aspects de la transmission de Platon dans l'Antiquité, Philosophie hellénistique et romaine 8, Turnhout, Brepols, 2018, 339 pp., ISBN: 9782503577890. Cloth: €95

\author{
Reseñado por CLELIA CRIALESI \\ Pontifical Institute of Mediaeval Studies, Toronto, CA \\ crialesi@lettere.uniroma2.it
}

The volume consists of ten chapters and is the result of the sixth Diatribai meeting, organised by Thomas Bénatouil, held in 2011 in Gargnano (Italy). This international conference and its proceedings are dedicated to the so-called Plato latinus, i.e. to the reception of Platonism in the Latin West area, from Cicero's to Boethius' time.

The editors, Jean-Baptiste Guillaumin and Carlos Lévy, open the book with a Présentation (pp. 7-29) which, despite its title, is not meant to offer an overview of the following chapters, but it is rather a chapter per se divided into two parts. The first part focuses on Cicero by presenting him as a pivotal thinker in the developments of Latin Platonism. Three main features of Cicero's philosophical thought are addressed: his first meeting with Platonism through Philolaus of Larissa; his non-supine approach to his masters' thought; his account of Plato as the first to develop a wellstructured way of engaging in philosophy (forma philosophiae). The second part of the study aims to define Latin Platonism by recalling topics which are addressed in the subsequent contributions: the reception and development of Platonic epistemology; the implications of the theory of knowledge in the field of ethics and politics; theology or rather the account of gods in the Latin Platonic corpus; the transmission of Platonic philosophy in the different forms of literature, and, finally, the renovation of the philosophical vocabulary.

In order to best present the content of the volume, it is useful to sort its contributions into three main categories: a) epistemology and metaphysics, b) practical philosophy and c) theology.

\title{
a) Epistemology and Metaphysics
}

T. Reinhardt, Antiochus of Ascalon on Epistemology in the Academic Tradition, pp. 3167. The paper is concerned with Antiochus of Ascalon's view on the development of Academic epistemology, which is reconstructed by analysing passages from Cicero's Academia that relate to Antiochus' thought. With this purpose in mind, Reinhardt shows that Antiochus (1) credited the veteres with a conceptualistic view of forms; (2) regarded the Stoic view on epistemology to be a response to challenges posed in the Thaetetus; and (3) did not criticise Aristotle for undermining the forms. The textual 
evidences reveal that Antiochus envisaged the cooperation of reason and the senses to be the common doctrinal thread of Academic epistemology (from Plato to the Stoics, through Aristotle).

P. Donini, Le fonti medioplatoniche di Seneca: Antioco, la conoscenza e le idee, pp. 105123. This study stems from two previous contributions by Donini (published in 1979 and 2011). It is strictly related to Reinhard's article, but it leads to different conclusions concerning Antiochus' doctrine of knowledge. The author shows quite effectively the merging of the Stoic and Platonic approach, via Aristotle, in Antiochus' epistemology. Unlike Reinhardt, Donini investigates Antiochian theory by including Seneca's Letters 58 and 65 among its textual references. In Letter 65 the (Aristotelian) immanent forms, i.e. the eide, are taken as sensible forms. These sources and Cicero's Luc. 30 - in which the notitiae rerum proceed from universal concepts collected by likeliness - suggest that, in Antiochus' thought, knowledge starts from sensible forms and ends with the (Aristotelian) universals.

A.-I. Bouton-Touboulic, Os illud Platonis: Platonisme, scepticisme et néoplatonisme dans le Contra Academicos d'Augustin, pp. 233-256. This contribution is intended to clarify Augustine's account of the history of Platonic philosophy in his Contra Academicos. In the latter as well as in Letter 118 to Dioscorus, Augustine looks at the development of the Academy with a conciliatory attitude, in such a way that the Scepticism of the New Academy appears to actually overshadow Plato's esoteric dogmatism. Hence, the New Academy can be harmonised with both Neoplatonism and Christianity, which represents the culmination of Platonic tradition. The author suggests that Plato's Phaedo - mediated by Porphyry's and Ambrosius' interpretation is the basis of Augustine's conception of Scepticism in his Contra Academicos. Nevertheless, this account was later rejected by Augustine in his City of God.

M.-J. Huh, Les questions sur les universaux dans le premier commentaire de Boèce à l'Isagogè et le debat Plotin-Porphyre autour de l'ousia, pp. 257-297. This chapter deals with the roots of Boethius' (first) reading of Porphyry's second and third questions on universals. Huh convincingly states that Boethius relies on Porphyry's metaphysics: a unique substance generates the class of the incorporeal beings (both the intellect and the soul) and that of bodily things (the physical reality). The textual evidences are cogent: (1) Boethius shares the same philosophical background as Simplicius' commentary on Aristotle's Categories, namely Porphyry's lost commentary on the Categories; (2) Boethius' explicit reference to Macrobius' prima incorporalitas is revealing of a notion stemming from Porphyry' commentary on Ptolemy's Harmonics; (3) Boethius has the same concern as Dexippus, i.e. the harmonisation of Aristotle's Categories and Plotinus' structure of realm by means of the notion of ousia. 


\section{b) Practical Philosophy}

F. Renaud, Le projet platonicien d'une rhétorique philosophique et son rapport à la politique, pp. 69-87. Renaud argues that Cicero's conception of philosophical rhetoric is better understood when considered as a response to Plato's Gorgias. Despite the many praises addressed to Socrates, the latter is the object of severe criticism by Cicero, whose De inventione and De oratore blame him for having dissociated philosophy from rhetoric, i.e. public from private speech, or theoretical life from socio-political engagement. The Ciceronian view about rhetoric is grounded in the Latin principle of decorum and aims to reconcile the needs of persuasion with truth. This emerges also from the Dream of Scipio: in presenting the analogy between public and cosmic order, both politicians and philosophers are rewarded once they reach the celestial world. Renaud finally notes that Cicero's peculiar place in the history of Latin Platonism can be considered also in light of his choice of taking part in the public life without ceasing to declare himself (and to be) a philosopher.

F. Prost, Le Laelius de Cicéron et le Lysis de Platon, pp. 89-103. In line with Renaud's study, Prost analyses Cicero's De amicitia by juxtaposing it with Plato's Lysis. Although Cicero does not mention this Platonic work and the link between the two texts is not explicit, some shared features are pointed out. Firstly, the structure of both dialogues: the main topic - i.e. friendship - is developed by discussing the respective 'antimodel' - in the Lysis, it is the friendship between men who are similar and dissimilar, whereas, in the De amicitia, it is the friendship which relies on fate. Secondly, the themes they address, namely (1) the inclusion of an impersonal element (i.e. the good or virtue) in friendship; (2) the potential lack of mutuality (friendship can involve also people from the past); (3) the moral quality of friends, who find a mutual way to improve themselves; and (4) a superior good which guides the relationship (virtue mirrors itself in the friends).

\section{c) Theology}

C. Moreschini, Dio e dèi in Apuleio, pp. 125-146. Moreschini deals with Apuleius' conception of God and gods and considers different loci of the whole Apuleian literary and philosophical corpus. In order to reconstruct Apuleius' doctrine of God, the author focuses on the divine attributes, especially his being summum bonum, beatus and beatificus, and activity (God is rector, origin and salvation of the world and operates providentially through intermediate potestates). The 'enotheism' (i.e. the existence of subordinates gods and daemons under a supreme God) is the conceptual frame within which Apuleius' idea of divine realm is structured.

A. Setaioli, La citazione di Plotino in Servio, Ad Aen. 9.182, pp. 147-165. Setaioli's article focuses on the demonology recalled by Servius in his scolium to Virgil's Aeneids 9.184-5. Servius comments upon Nisus' question concerning whether human action and reason are guided by god. He improperly recalled Plotinus' theory of daemon by 
stating that every man being guided by an external daemon is not responsible for his good actions. This misinterpretation might have been caused by Servius' reading Plotnius' Enneads (3.2-3.4) via an indirect source. Thus Setaioli investigates other Latin and Greek thinkers who shared the same perspective with regard to their demonology, such as Apuleius (in De deo Socratis), Plutarch (in De genio Socratis), Porphyry (in his biography of Plotinus), and Ammianus Marcellinus (in his report of the death of the emperor Costantius). With regard to the latter, Setaioli notes that Ammianus' account, which includes a quotation from the comedian Menandrus, is the most convergent with Servius' text.

J.-B. Guillaumin, De la représentation mythologique à l'ontologie néoplatonicienne: rôle et statut des dieux chez Martianus Capella, pp. 167-205. This study focuses on the status of gods in Martianus Capella's Marriage of Philology and Mercury. Guillaumin sets out three ways of looking at gods in Martianus' narrative. Firstly, he takes into account the syncretic approach. Gods are introduced by means of their astral counterpart and are physically characterized in accordance with both Roman mythology and Etruscan, Phoenician, and Egyptian religious imagery. Secondly, gods are considered with regard to their contribution to Philology's mystical and astral itinerary towards knowledge. Philology is a personification of the human soul and gods are like powers acting on it, by purifying it and contributing to its return to its own transcendence. Finally, the place of gods in the world is found in their hierarchical order culminating in the only one transcendent and ineffable divinity. Many of them, such as Hymen, Mercury, or Juppiter, are responsible for the cohesion of the elements structuring the world, similarly to the ontological function of the Neoplatonic second hypostasis.

B. Bakhouche, Les Hebraica dans le commentaire su Timée de Calcidius, pp. 207-232. Bakhouche analyses the references to the old Testament and the Jews, which are gathered in the second part of Calcidius' Commentary on the Timaeus dealing with soul and matter. The use of these references by Calcidius is twofold: it shows the doxographic distance from the Platonic scholarship, but it also serves to confirm the Platonic theories. From the Hebraica we derive a consistent philosophical representation of the Jews. Their ideas are aligned with the medio-platonic tradition on the basis of their conception of daemons and fate, and are characterized by a gnostic dualism, especially when they deal with the good and the bad soul, which derive respectively from matter and God. This evidence induces us to assume that the auditores Platonis, as the Jews are defined in chapter 300 of the Commentary, could be the adherents of the 'sect of Seth'.

By way of conclusion, it is worth mentioning the presence of two Indices at the end of the volume: the first one gathers the bibliography, and the second one the loci of Ancient authors mentioned in the studies. 